\title{
Religião e ideologia em Ruy Belo: alguns apontamentos
}

\author{
Natália Ubirajara Silva ${ }^{1}$
}

\begin{abstract}
This article describes the questioning of Catholicism in the work Homem de Palavra[s], by Portuguese poet Ruy Belo. Through the reading of the poems "Nós os vencidos do catolicismo", "Soneto superdesenvolvido" and "O portugal futuro", it tries to verify, in dialog with concepts of Marxist philosophy, in which ways the Catholic ideology and its influence in Portuguese society during the Salazar years are problematized in Belo's poetic writing.
\end{abstract}

Keywords: Portuguese literature; Ruy Belo; Catholicism; Marxism; ideology

Resumo: O presente artigo discute o questionamento do catolicismo na obra Homem de Palavra[s], do poeta português Ruy Belo. A partir da leitura dos poemas "Nós os vencidos do catolicismo", "Soneto superdesenvolvido" e "O portugal futuro", procura-se verificar, num diálogo com conceitos da filosofia marxista, de que forma a ideologia católica e sua influência na sociedade portuguesa durante os anos do salazarismo são problematizadas no fazer poético de Belo.

Palavras-chave: literatura portuguesa; Ruy Belo; catolicismo; marxismo; ideologia

\section{Introdução}

O poeta português Ruy Belo (1933-1978) foi um incompreendido. Criado em lar católico, praticou sua fé até a vida adulta. Membro da Opus Dei e doutor em Direito Canônico pela Pontifícia Universidade de Estudos São Tomás de Aquino, em Roma, Belo passou a ser alijado do meio católico por suas amizades, ideias e produção poética. Ao mesmo tempo, por ser católico, também era visto com reservas no meio intelectual português; prova disso é que em 1978, ano de sua morte prematura, o poeta, tradutor, crítico e ensaísta era professor secundário e estava em vias de concorrer a uma vaga de professor universitário. Muitas portas profissionais se fecharam ao autor devido a seus posicionamentos (cf. SILVA apud REVEZ, 2009, p. 138). Independente, Belo não se filiou a agremiações literárias; questionador, não ficou preso às amarras do catolicismo institucionalizado e aparelhado ideologicamente pelo Estado Novo de Oliveira Salazar.

Eugénio de Andrade expressa a posição de Belo na cultura portuguesa em seu poema "À memória de Ruy Belo":

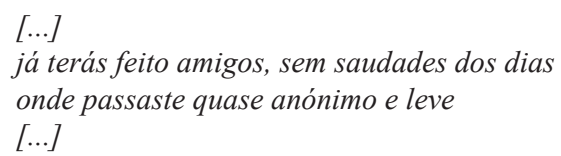

1 Doutoranda em Literaturas Portuguesa e Luso-africanas no Programa de Pós-Graduação em Letras da UFRGS 


\section{Conexão Letras}

Consola-me ao menos a ideia de te haverem

deixado em paz na morte; ninguém na assembleia

da república fingiu que te lera os versos,

ninguém, cheio de piedade por si próprio,

propôs funerais nacionais ou, a título póstumo,

te quis fazer visconde, cavaleiro, comendador,

qualquer coisa assim para estrumar os campos.

Eles não deram por ti, e a culpa é tua,

foste sempre discreto (até mesmo na morte),

não mandaste à merda o país, nem nenhum ministro (ANDRADE, 1984, p. 76-77).

O sujeito lírico de Andrade elogia a falta de homenagens póstumas a Ruy Belo, a qual significaria a não assimilação do poeta por parte do sistema religioso e político vigente: "para neutralizar a literatura, pode-se prender, exilar, assassinar os escritores ou então assimilá-los, integrá-los, cooptá-los [...] condecorando-os com a Ordem disso e daquilo, colocando-os no primeiro lugar de uma lista dos mais lidos" (TENÓRIO, 2014, p. 67). Felizmente, não foi isso que ocorreu com Ruy Belo; a cultura oficial limitou-se a silenciar quanto a sua obra.

A trajetória desse poeta discreto, de projeção inversamente proporcional à qualidade de sua produção, é a de um homem atormentado pela dúvida quanto à fé que aprendera e pregara. A “cosmovisão bíblica” (REAL, 1998, p. 181) segundo a qual sua mentalidade se plasmara se choca com a realidade: ao lançar Homem de Palavra[s], em 1969, Ruy Belo está em crise. Em 1978, nove anos após a publicação, Belo escreve um prefácio à segunda edição do livro e rebate as críticas recebidas:

No balanço que, em finais de 1969, publicou sobre livros de poesia que nesse ano apareceram, um crítico literário que aliás muito prezo disse que, com este Homem de Palavra[s] eu, como poeta, me havia desencontrado. Ora eu creio que isso não aconteceu, embora só agora o diga. O que aconteceu foi que mais uma vez a crítica [...] se ficou num livro passado de um autor para o voltar contra seus livros futuros, como se seus não fossem igualmente (BELO, 2004, p. 243).

O poeta reconhece em Homem de Palavra[s] uma viragem temática e estilística em comparação com suas obras mais conhecidas, como Aquele Grande Rio Eufrates (1961) e Boca Bilingue (1966). No processo de composição desse livro, Ruy Belo desafiou-se a nunca repetir-se: "Em Homem de Palavra[s], parece-me ter escrito poemas, introduzido processos, buscado formas que nunca escrevera, introduzira ou buscara até então" (BELO, 2004 , p. 243). Os críticos, contudo, tomaram as obras anteriores como paradigma e, com isso, desprezaram as inovações que o poeta trouxe em Homem de Palavra[s]. Essa visão limitada de sua obra perdura em certas recensões à obra do autor. Massaud Moisés, por exemplo, em seu famoso livro A literatura portuguesa, afirma que as experiências religiosas de Belo oferecem aos seus poemas “calma e paz” (MOISÉS, 2008, p. 472), ignorando a profunda crise religiosa que se percebe em Homem de Palavra[s] e em textos posteriores.

Ao revisitar sua obra, o poeta reconhece o tom de "vão catolicismo" (BELO, 2004, p. 244) que a permeia; sustenta, porém, que a presença de elementos cristãos nos poemas não representa adesão à religião cristã enquanto instituição: "Se as epígrafes pedidas à Bíblia conferissem o cariz cristão a quem delas se socorre muitos autores teriam de ser considerados cristãos, quando tal ideia nunca lhes teria passado pela cabeça nem pelo coração" (BELO, 2004, p. 244). Quanto a isso, o poeta é categórico: “O clima do livro já não é o da fé, aliás perdida" (BELO, 2004, p. 244). Isso se confirma em sua trajetória posterior: 
Consumada a sua ruptura com a Igreja, inicia-se o que podemos designar como um período de afastamento. Ruy Belo não rompe simplesmente com o catolicismo mas caminha por um longo processo de questionação da fé, afirmando Joaquim Manuel Magalhães [...] que o poeta se encontraria no final da sua vida numa situação de completo agnosticismo (REVEZ, 2009, p. 137).

A negação da fé se traduz até mesmo na grafia das palavras. A análise do espólio do poeta é reveladora:

Aquele Grande Rio Eufrates, o livro de estreia, é um caso à parte. Quando publicou a primeira edição (Ática, 1961), o poeta saíra há pouco de uma década na Opus Dei. Na edição da Moraes, em 1972, decidiu suprimir as maiúsculas no desejo de que "palavra alguma levante a cabeça no meio da frase", incluindo "o lexema 'deus"." Tudo isto é história conhecida. A partir daqui é interessante ver no espólio como, algures entre 1972 e 1978 - entre a segunda edição e a morte - Ruy Belo eliminou, riscando a lápis todas as referências a deus no exemplar da $2^{a}$ edição pertencente a Teresa Belo: "Descobri isto há uns anos e de facto lembro-me de ele manusear este exemplar." Seria o que estava mais à mão.

Alguns exemplos: no primeiro poema, onde está "o senhor", Ruy Belo risca e escreve "alguém"; no segundo poema, onde está "senhor deus", risca e escreve "aquele olhar"; e por ai fora, riscando sempre "deus", "senhor", "cruz", e escrevendo por cima, "artista", "justiça" ou mesmo "alguma coisa" (COELHO, 2003).

Homem de Palavra[s] é um ponto importante nesse processo de afastamento da cosmovisão religiosa. Apesar de Ruy Belo não se declarar marxista, vários dos poemas aproximam-se de conceitos dessa filosofia. Como diz Paz, "el marxismo ha penetrado tan profundamente en la historia que todos, de una manera u outra, a veces sin saberlo, somos marxistas. [...] Este pensamiento es ya parte de nuestra sangre intelectual"' (1972, p. 258).

\section{1 "Nós os vencidos do Catolicismo": Religião e desistência}

Os três grandes temas de Homem de Palavra[s] são anunciados na série "Portugal sacro-profano", no poema "Lugar onde". São eles: "País poema homem" (BELO, 2004, p. 259). Acreditamos que esses três grandes temas são problematizados em sua relação com o catolicismo. A fé que transparecia nas obras anteriores é questionada, como vemos em "Nós os vencidos do catolicismo" (BELO, 2004, p. 269):

\section{NÓS OS VENCIDOS DO CATOLICISMO}

Nós os vencidos do catolicismo que não sabemos já donde a luz mana haurimos o perdido misticismo nos acordes dos carmina burana

Nós que perdemos na luta da fé não é que no mais fundo não creiamos mas não lutamos já firmes e a pé nem nada impomos do que duvidamos

Já nenhum garizim nos chega agora depois de ouvir como a samaritana que em espirito e verdade é que se adora Deixem-me ouvir os carmina burana 
Nesta vida é que nós acreditamos

e no homem que dizem que criaste

se temos o que temos o jogamos

"Meu deus meu deus porque me abandonaste?"

O poema se divide em quatro quartetos e tem ritmo impresso pelo uso de metro regular (decassílabo). As palavras sobre as quais o acento tônico recai são importantes para a construção do sentido; destacamos: "vencidos", "catolicismo", "já", "perdido misticismo", "carmina burana", "perdemos", "fé", "agora", "acreditamos" e "abandonaste". A rima e o ritmo criam imagens de perda e derrota, negação, abandono, desistência.

As rimas externas seguem o esquema $\mathrm{ABAB}$; $\mathrm{CDCD}$; EBEB; DFDF. A repetição das rimas $\mathrm{B}$ (terceira estrofe) e $\mathrm{D}$ (quarta estrofe) estabelece relações entre os versos, conforme a teoria do estruturalista russo Iuri Lotman. Segundo essa teoria, a rima "reenvia o leitor para o texto precedente" (LOTMAN, 1978, p. 216), criando uma rede de equivalências. Assim, temos:

nos acordes dos carmina burana (v. 4)

Deixem-me ouvir os carmina burana (v. 10)

não é que no mais fundo não creiamos (v. 6)

Nesta vida é que nós acreditamos (v. 13)

O sujeito lírico é expresso pelo pronome pessoal "nós", ou seja, não representa a voz de apenas um indivíduo, mas de todo um grupo a vivenciar a mesma derrota. Esse sujeito lírico coletivo se define como "vencido do catolicismo", tendo se afastado da fé de outrora, e representa uma geração de católicos portugueses que, após viverem intensamente a religiosidade institucional, começaram a se desiludir.

Esse espírito de geração é corroborado pelo diálogo entre a expressão "vencidos do catolicismo" e o grupo "Vencidos da vida" (1888-1894), grupo de 11 intelectuais (dentre os quais Oliveira Martins, Guerra Junqueiro e Eça de Queirós) que se reuniam em Lisboa para jantar e discutir a situação de Portugal. Esses pensadores participaram ativamente nas Conferências do Cassino Lisbonense em maio de 1871, nas quais as novidades culturais e filosóficas do século XIX, como o marxismo, foram introduzidas no contexto lusitano. Em decorrência das teorias marxistas, um dos tópicos discutidos em 1871 foi a decadência portuguesa devido ao catolicismo, religião atrelada às políticas e interesses do Estado. Antero de Quental, na conferência "Causas da decadência dos povos peninsulares nos últimos três séculos", atribui o apequenamento de seu país à "transformação do catolicismo operada pelo Concílio de Trento" (QUENTAL, 1871, p. 19).

Mais de quinze anos depois, nos jantares dos "Vencidos da Vida", o catolicismo continuou a ser profundamente discutido. O grupo não era anticlerical de todo, mas questionava os sacramentos e a noção de pecado, por exemplo. Dizer-se "vencidos" equivale a reconhecer que as revoluções esperadas após a realização das Conferências de 1871 não se concretizaram.

Como os "Vencidos da vida", o sujeito lírico do poema de Belo demonstra ser a voz de uma geração derrotada. No prefácio à segunda edição de Homem de Palavra[s], Ruy Belo menciona a observação de um amigo: "Nós os vencidos do catolicismo' seria o poema de uma geração, [...] um definitivo abandono dos homens por parte de Deus" (BELO, 2004, p. 248). Ser "vencido", nos dois casos, é quase um programa de vida. Se considerarmos 
a biografia de Ruy Belo, veremos como o poeta se tornou um dissidente do catolicismo ao verificar que a Igreja - da qual participara ativamente, como membro da Opus Dei apresentava uma "função justificadora" (RICOEUR, 2011, p. 85) da ideologia do Estado Novo. Belo e sua geração reconheceram na Igreja Católica portuguesa aquilo que Althusser chama de "aparelho ideológico de Estado religioso" (1974, p. 43).

No segundo verso do poema, percebe-se desorientação ("não sabemos já donde a luz mana"); a tônica no advérbio "já" salienta a condição de perda das certezas - antes, sabíamos; agora, não mais. Antes, havia luz, conhecimento, certeza; agora, não sabemos de onde a luz brota. O sentimento é de instabilidade. No terceiro verso, lemos que o misticismo, outrora haurido na espiritualidade católica, agora é sorvido na melodia dos Carmina Burana, alusão intertextual aos cantos profanos medievais escritos ao longo do século XIII e à cantata homônima do alemão Carl Orff (1936). Ambas as referências são profanas, trazendo aspectos satíricos e eróticos. Desse modo, haurir dos Carmina Burana o misticismo demonstra não só abandono da fé católica, mas busca do misticismo na concretude da vida.

Em sua análise sobre hermenêutica e ideologia, Ricoeur explica a visão marxista de religião como deformação por inversão (RICOEUR, 2011, p. 83). O filósofo parte da metáfora do reflexo, apresentada por Marx e Engels em A ideologia alemã:

E se, em toda a ideologia, os homens e suas relações nos aparecem de cabeça para baixo como em uma câmera escura, esse fenômeno decorre de seu processo de vida histórico, exatamente como a inversão dos objetos na retina decorre de seu processo de vida diretamente físico (MARX; ENGELS, 2001, p. 19).

Sobre isso, Ricoeur explica: "o fato de a religião poder prestar-se a essa função [de justificadora da ideologia de Estado], enquanto inversão das relações do céu e da terra, significa que ela não é mais religião, vale dizer, inserção da Palavra no mundo, porém imagem invertida da vida" (RICOEUR, 2011, p. 85). No poema de Belo, o sujeito lírico rejeita essa imagem invertida da vida - o misticismo haurido no catolicismo -, preferindo os Carmina Burana - a "vida material" (MARX; ENGELS, 2001, p. 89). Uma das epígrafes de Homem de Palavra[s], embora bíblica, ratifica essa opção: "Aquele que é da terra, pertence à terra e fala da terra" (Jo 3,31). A exaltação do hoje e do material também aparece nos últimos versos de "Palavras de Jacob depois do sonho": "Aqui - mulher terra mar - / Aqui só pode ser a casa de deus" (BELO, 2004, p. 283). Também em Homem de Palavra[s], o dístico "Requiem por um bicho" nega a transcendência: "Está tudo muito certo mas a gata / que outro mundo trará a gata que morreu?" (BELO, 2004, p. 270).

Voltando a "Nós os vencidos do catolicismo", vemos como o poema expressa o momento de desconfiança e desistência por que os católicos portugueses passavam. No primeiro verso do segundo quarteto, retoma-se o pronome "nós"; além de vencido do catolicismo, o sujeito lírico foi derrotado na luta da fé, como se depreende da primeira estrofe. Na segunda estrofe, porém, ele explica o que vem a ser essa perda da fé: "não é que no mais fundo não creiamos / mas não lutamos já firmes e a pé / nem nada impomos do que duvidamos". Percebe-se aqui a repetida negação (por meio da repetição do advérbio "não" e de "Nem nada"). O sujeito lírico deixa claro que não perdeu totalmente a fé: seu desencanto parece ser com a fé institucionalizada, dogmatizada. A fé permanece, mas no terreno íntimo ("mais fundo"). Já não se luta para defender as crenças; não se impõe a fé, visto que o sujeito lírico tem, ele mesmo, muitas dúvidas. O sentimento de desistência retorna de forma pungente no poema "Cinco palavras cinco pedras", em que o sujeito lírico 


\title{
Conexão Letras
}

salienta a contraposição entre o presente (perda da fé e desistência) e o passado (tempo em que os deuses eram grandes):

\author{
Antigamente escrevia poemas compridos \\ Hoje tenho quatro palavras para fazer um poema \\ São elas: desalento prostração desolação desânimo \\ E ainda me esquecia de uma: desistência \\ […] \\ Antigamente quando os deuses eram grandes \\ Eu sempre dispunha de muitos versos \\ Hoje só tenho cinco palavras cinco pedrinhas (BELO, 2004, p. 272).
}

A terceira estrofe de "Nós os vencidos do catolicismo" também se centra na perda da fé. Agora, nenhum Garizim (grafado com minúsculas) chega. Garizim ou Gerezim é um monte da Cisjordânia citado na Bíblia. No Antigo Testamento, era um território sagrado de sacrifício e adoração para os samaritanos; no Novo testamento, é o local de um marcante encontro entre Jesus Cristo e uma samaritana ao lado do poço de Jacó. Diz o texto bíblico:

Nossos pais adoraram neste monte [Garizim], mas vós dizeis que é em Jerusalém que se deve adorar. Jesus respondeu: Mulher, acredita-me, vem a hora em que não adorareis o Pai, nem neste monte nem em Jerusalém. Vós adorais o que não conheceis, nós adoramos o que conhecemos, porque a salvação vem dos judeus. Mas vem a hora, e já chegou, em que os verdadeiros adoradores hão de adorar o Pai em espírito e verdade, e são esses adoradores que o Pai deseja (Jo 4:20-23).

Jesus Cristo diz à samaritana que ela não irá mais adorar no Garizim, mas em espírito e em verdade. O sujeito lírico se alinha à figura da samaritana, tendo ouvido, como ela, as palavras de Jesus Cristo; o monte aparece como metáfora da fé mediada pela Igreja, local de adoração institucionalizado. Ao dizer que nenhum Garizim pode satisfazê-lo, o sujeito lírico, de maneira forte, renega a Igreja. Ele ordena: "deixem-me ouvir os Carmina Burana"; em vez de hinos de louvor, prefere ouvir cantos que dessacralizam e desautorizam a ideologia católica. Sua fé pode ser em espírito e verdade, sem a constrição que a adesão à crença institucionalizada proporciona.

Depois de três estrofes com o predomínio de imagens de negação e perda, o último quarteto nos apresenta uma afirmação sobre a fé no tempo da enunciação: "Nesta vida é que nós acreditamos". Essa rima (v. 13), como dissemos anteriormente, ecoa a rima do verso "não é que no mais fundo não creiamos" (v. 6). Há uma crença, sim, embora não a antiga. Hoje, o sujeito lírico crê na vida (v. 13) e no homem (v. 14), concordando com Marx e Engels quando estes afirmam que "é na práxis que o homem precisa provar a verdade, isto é, a realidade e a força, a terrenalidade do seu pensamento" (2001, p. 100). O sujeito lírico rejeita o idealismo, vinculando-se à visão materialista da vida. Ainda nesta última estrofe, revela-se a identidade do interlocutor: o Deus cristão, aquele que - dizem - criou o homem (v. 14). A interlocução com esse Criador questionado configura o poema como espécie de oração daquele que já não tem fé, um Credo do descrente.

A despeito da afirmação sobre a crença na vida e no homem, o tom melancólico se mantém ao fim do poema: o sujeito lírico parece se ressentir com a destruição das certezas e lamenta, em total abandono, como o salmista (S1 21) e Jesus Cristo na cruz: "Meu deus [com minúsculas, dessacralizando o nome divino], meu deus, porque me abandonaste?". Os últimos versos constroem uma imagem de solidão, abandono e de saudade do tempo em que o misticismo e a fé eram certezas imutáveis. 
Em uma de suas mais conhecidas citações, Marx afirma que a "tradição de todas as gerações mortas oprime como um pesadelo o cérebro dos vivos" (s.d., p. 6). Os portugueses vencidos do catolicismo, advindos de uma "cristalização duradoura de uma mentalidade judaico-cristã” (REAL, 1998, p. 182), sofrem com a perda dessa tradição, órfãos da antiga visão de mundo que pautara suas existências.

\title{
2 "Soneto Superdesenvolvido": Caridade cristã e sua função justificadora
}

Outro poema-denúncia da religião como imagem invertida da vida é "Soneto superdesenvolvido" (BELO, 2004, p. 265). Nele, o sujeito lírico ironiza a visão edulcorada que a religião constrói acerca da realidade:

\author{
SONETO SUPERDESENVOLVIDO \\ É tão suave ter bons sentimentos \\ consola tanto a alma de quem os tem \\ que as boas acções são inesquecíveis momentos \\ e é um prazer fazer bem \\ Por isso no verão se chega a uma esplanada \\ sabe melhor dar esmola a beber laranjada \\ Consola mais viver assim no meio de muitos pobres \\ que conviver com gente a quem não falta nada \\ E ao fim de tantos anos a dar do que é seu \\ independentemente da maneira como se alcançou \\ ainda por cima se tem lugar garantido no céu \\ gozo acrescido ao muito que se gozou \\ Teria este (se não tivesse outro sentido) \\ ser natural de um país subdesenvolvido
}

Neste soneto elisabetano - formado por três quartetos e um dístico conforme o esquema rímico $\mathrm{ABAB}$; $\mathrm{CCDC}$; $\mathrm{EFEF}$; GG -, o sujeito lírico apresenta uma visão "superdesenvolvida" ou, nos termos de Marx, uma visão invertida. Ironiza-se a atitude cristã de caridade, por parte dos ricos, e de resignação por parte dos pobres; a repetição dos vocábulos "tanto" e "tão" reforçam o tom irônico do poema. As expressões "suave", "bons sentimentos", "consola", "alma”, "boas ações", "inesquecíveis momentos" e "prazer", na primeira estrofe, formam um arquissema (cf. LOTMAN, 1978, p. 251), formando a imagem de uma alma cristã benfazeja e caridosa. Há uma ideia de consequência: ter bons sentimentos é tão suave e consola tanto aquele que os tem, que as boas ações praticadas se tornam inesquecíveis. A rima entre "sentimentos" (v. 1) e "momentos" (v. 3) indica que, na verdade, esses atos de caridade não são tão rotineiros quanto se dá a entender. Desvela-se a máscara do altruísmo: ao realizar tantas "boas ações", o indivíduo procura sua própria consolação, um prazer particular.

Essa visão romântica e franciscana permanece na segunda estrofe, na qual se diz que dar esmola - quando se está, comodamente, em melhor condição social que o outro - é mais saboroso do que beber laranjada (v. 6). A alma que tem bons sentimentos vive em uma classe social "a quem não falta nada" (v. 8) e dar esmola se torna um lazer, entre- 


\section{Conexão Letras}

tenimento, passatempo de verão. A condição de desigualdade fica exposta por meio do pronome "muitos" (v. 7): não são poucos os pobres. O vocábulo "pobres" (v. 7), aliás, é o único em fim de verso sem rima externa ao longo de todo o soneto (há rima interna com "esmola", no sexto verso). Não há lugar nem voz para os pobres: eles servem apenas como um meio pelo qual o benfeitor pode realizar boas ações e garantir sua satisfação pessoal; a eles, resta esperar pela caridade e crer que sua miséria será recompensada no céu. Esse é, aliás, um dos princípios cristãos condenados por Marx e Engels:

Os principios sociais do cristianismo pregam a necessidade de uma classe dominante e de uma classe oprimida e só têm a oferecer a esta o piedoso desejo de a primeira dignar-se ser caridosa.

Os princípios sociais do cristianismo colocam no céu esse desagravo de todas as infâmias de que fala nosso conselheiro, justificando assim sua permanência na terra (MARX; ENGELS apud LECOMPTE, 2000, p. 133-134)

Não podemos deixar de reconhecer nessa divisão em classes a ideologia salazarista de exaltação do Portugal rural e retrógrado, a qual moldou uma imagem nacional justificadora do atraso e da desigualdade baseando-se na visão de mundo cristã. Também sobressai, na segunda estrofe, o contraste entre duas classes de cidadãos: os pobres e aqueles a quem não falta nada, espelhando a divisão marxista entre ideólogos ativos e passivos:

Uns serão os pensadores dessa classe (os ideólogos ativos, que teorizam e fazem da elaboração da ilusão que essa classe tem de si mesma sua substância principal), ao passo que os outros terão uma atitude mais passiva e mais receptiva em face desses pensamentos e dessas ilusões, porque eles são na realidade os membros ativos dessa classe e têm menos tempo para alimentar ilusões e ideias sobre suas próprias pessoas (MARX; ENGELS, 2003, p. 49).

No terceiro quarteto do poema, o pronome "seu" (v. 9) reforça a noção de posse: quem tem bons sentimentos é também aquele que tem bens materiais; o fato de possuir mais bens e capitais do que os outros não é questionado, bem como a origem desses bens (v. 10). A rima entre "seu" (v. 9) e "céu" (v. 11) compõe a imagem de compra e posse de um lugar no céu por meio das boas ações praticadas. Desvelam-se os verdadeiros fins da caridade cristã: a oferta de esmolas oriundas dos bens acumulados não é desinteressada, garantindo consolo pessoal (satisfação por reconhecer-se bom) e abrindo caminho para ainda mais benefícios na outra vida. O contraste com o ensinamento evangélico - "é mais fácil o camelo entrar pelo buraco de uma agulha do que o rico entrar no Reino de Deus" (Lc 18,25) - é gritante, numa inversão do texto bíblico. Como aponta Galimberti,

para livrar-se da contradição, a doutrina social da Igreja esquece que, como condição para a salvação da alma, Jesus exige do jovem rico que entregue todos os seus bens aos pobres, enquanto a Igreja, vestindo as roupas do bom senso, manda aos ricos de hoje que deem o mais possivel para evitar que se arruinem (2003, p. 335).

O dístico final rompe o ritmo do poema e "provoca uma expectación" (PAZ, 1972, p. 57). Nele, o sujeito lírico revela, concordando com Antero de Quental, que a alegada vivência dos valores cristãos pela classe dominante resulta na decadência de Portugal. Embora a ideologia católico-salazarista apregoe um império superdesenvolvido, o país é, na realidade, subdesenvolvido em virtude da acomodação, elemento que aparece em outros 
poemas: "Invadia-nos um íntimo torpor" (BELO, 2004, p. 258), "Neste país sem olhos e sem boca" (BELO, 2004, p. 259), "desistência desalento prostração desolação desânimo" (BELO, 2004, p. 272), "deixo cair os braços o esquerdo e o direito" (BELO, 2004, p. 286), "e a minha maneira de me matar / é deixar cair ambos os braços" (BELO, 2004, p. 287).

Seguindo a ideologia de acomodação vigente, as almas ditas boas contentam-se com a recompensa celeste, que as exime de atuar sobre o presente a fim de modificá-lo, e as almas pobres se consideram bem aventuradas, abençoadas pela sua condição miserável. Mais uma vez, Belo percebe a função de aparelhamento ideológico da religião. Segundo Althusser, ideologia e classe dominante andam juntas:

Se quisermos considerar que em princípio a "classe dominante" detém o poder de Estado (de uma forma franca ou, na maioria das vezes, por meio de Alianças de classe ou de fracções de classes), e dispõe portanto do Aparelho (repressivo) de Estado, podemos admitir que a mesma classe dominante é activa nos Aparelhos ideológicos de Estado (1974, p. 48).

Na Bíblia, o pobre é valorizado e o rico é execrado - vide parábola do rico e Lázaro (Lc 16:19-31); porém, a hegemonia da classe dominante (cf. ALTHUSSER, 1974, p. 49) sobre o aparelho ideológico religioso subverte a lógica do Evangelho. De acordo com Marx e Engels,

Os pensamentos da classe dominante são, também, em todas as épocas, os pensamentos dominantes; em outras palavras, a classe que é o poder material dominante numa determinada sociedade é também o poder espiritual dominante. A classe que dispõe dos meios da produção material dispõe também dos meios da produção intelectual, de tal modo que o pensamento daqueles aos quais são negados os meios de produção intelectual está submetido também à classe dominante. Os pensamentos dominantes nada mais são do que a expressão ideal das relações materiais dominantes; eles são essas relações materiais dominantes consideradas sob forma de ideias, portanto a expressão das relações que fazem de uma classe a classe dominante; em outras palavras, são as ideias de sua dominação (MARX; ENGELS, 2001, p. 48).

A fim de justificar a manutenção do status quo e de mascarar a incongruência entre este e a pregação evangélica, prega-se a beleza da pobreza, o contentamento com o estado de vida e o não questionamento das desigualdades. O poema de Ruy Belo denuncia o louvor à estagnação empreendido pela ideologia salazarista e religiosa, que prega a resignação diante da condição atual sob a forma da universalidade, representando seus pensamentos como "os únicos razoáveis, os únicos universalmente válidos” (MARX; ENGELS, 2003, p. 50). Assim, segundo a teoria de Gramsci, os conceitos religiosos

[...] podiam cimentar valores e desejos populares, dito de outro modo, poderiam sistematizar valores difusos, dispersos na sociedade, e consolidar uma visão de mundo compreendida, aceita e legitimada. Na Itália, a religião detinha este poder simbólico de emoldurar a cultura e constituir um elo entre a razão e a crença. Neste sentido a fé geraria a identidade popular (SILVA, s.d.).

Como na Itália, a visão de mundo portuguesa configurou-se de acordo com uma ideologia religiosa de dominação, a qual emoldurou a cultura e a identidade popular lusitanas. Essa ideologia de dominação coaduna-se à do Estado Novo, e sua dominação é garantida por meio da repressão às dissidências: 
Gramsci nos municia com dois instrumentos conceituais necessários para o esboço das funções históricas de uma igreja na sociedade, são eles: a ideia de religião como uma forma de ideologia especifica e a ideia da religião como aparelho ideológico. E é esta segunda atitude que Gramsci considera como opiácea, pois ela compreende uma fase de declínio em que a religião perdeu sua função histórica e tem sobrevida devido aos mecanismos de repressão por ela adotados. (SILVA, s.d.).

O papel repressor da religião é apontado por Belo no prefácio a Homem de Palavra[s], quando este afirma que o Cardeal Cerejeira "infiltrara nas consciências os temores e receios que Salazar instilara exteriormente na ordem - nas ruas, nos fortes, nas próprias casas populares" (BELO, 2004, p. 248). Os mecanismos de repressão do aparelho religioso atuam na consciência, impedindo o pensamento livre e levando à passividade:

A partir desse momento, a ideologia religiosa tornou-se um freio à iniciativa das massas, à sua emancipação política, mantendo-as na passividade. É nesse sentido que a religião não é automaticamente ópio do povo, ela se torna tal, na medida em que, superada por uma "concepção superior do mundo" impede toda evolução (SILVA, s.d.)

\section{3 “O Portugal futuro": Projeção de um novo começo}

Apesar do quadro de desistência e repressão formado por "Nós os vencidos do catolicismo" e "Soneto superdesenvolvido", ainda há esperança. O sujeito lírico criado por Ruy Belo se permite sonhar com "O portugal futuro" (BELO, 2004, p. 264):

\section{O PORTUGAL FUTURO}

O portugal futuro é um pais

aonde o puro pássaro é possivel

e sobre o leito negro do asfalto da estrada

as profundas crianças desenharão a giz

esse peixe da infância que vem na enxurrada

e me parece que se chama sável

Mas desenhem elas o que desenharem

é essa a forma do meu país

e chamem elas o que lhe chamarem

portugal será e lá serei feliz

Poderá ser pequeno como este

ter a oeste o mar e a espanha a leste

tudo nele será novo desde os ramos à raiz

À sombra dos plátanos as crianças dançarão

e na avenida que houver à beira-mar

pode o tempo mudar será verão

Gostaria de ouvir as horas do relógio da matriz

mas isso era o passado e podia ser duro

edificar sobre ele o portugal futuro

Esse poema diferencia-se dos anteriores, pois apresenta apenas uma estrofe com 19 versos. Há uma divisão explícita em cinco blocos, indicados pelas iniciais maiúsculas. Valendo-nos da teoria de Lotman (1978), agruparemos os versos do poema segundo suas equivalências; no caso, nosso critério será rímico, buscando relações de sentido estabelecidas pela identidade sonora. 
O primeiro arquissema formado por meio das rimas reúne imagens que elaboram o Portugal futuro como felicidade possível, novidade, infância e apagamento do tempo antigo: "O portugal futuro é um país" (v. 1); "as profundas crianças desenharão a giz" (v. 4); "é essa a forma do meu país" (v. 8); "portugal será e lá serei feliz" (v. 10); "tudo nele será novo desde os ramos à raiz" (v. 13); "Gostaria de ouvir as horas do relógio da matriz" (v. 17). O uso do vocábulo "país" em lugar de "pátria" é deliberado: "contraponho - dizia eu - à palavra 'pátria' a palavra 'país', humilde e discreta" (BELO, 2004, p. 245). Em "Lugar onde", poema da série "Portugal sacro-profano", a diferenciação entre os dois vocábulos é explicitada: "país palavra húmida e translúcida / palavra tensa e densa com certa espessura / (pátria de palavra tem apenas a superfície" (BELO, 2004, p. 259). No poema "Aos homens do cais", o sujeito lírico ratifica: "Portugal não é pátria mas país" (BELO, 2004, p. 267). "Pátria" seria uma palavra ideologicamente carregada, representando a imagem salazarista de Portugal como grande império ultramarino predestinado por Deus.

O segundo arquissema traz duas figuras do mundo animal: "aonde o puro pássaro é possível” (v. 2) e "e me parece que se chama sável” (v. 6). Ambos, pássaro e sável, remetem a um tempo original: o pássaro é puro; o sável, peixe migratório já extinto, revive no desenho das crianças. Se recorrermos ao método das passagens paralelas (COMPAGNON, 2006, p. 68), leremos no poema "O maná do deserto" que as aves passam e ficam "só nos versos do poeta" (BELO, 2004, p. 258); o puro pássaro poderia ser, pois, uma metáfora para o fazer poético. Essa leitura é corroborada pelo poema "A minha tarde": "passam as aves em seu voo rasante / desde sá de miranda até jorge de sena" (BELO, 2004, p. 281). Outra interpretação possível seria considerar esse "puro pássaro" uma metáfora da liberdade.

No novo Portugal sonhado por Belo, crianças desenharão um sável; as crianças e o animal extinto reforçam a imagem de um novo começo, retorno à origem. $\mathrm{O}$ tom otimista de "O portugal futuro" pode ser explicado por meio da contextualização histórica: em 1969, Marcello Caetano assumiu o poder, o que provocou em Portugal a esperança de que o ciclo salazarista estaria se encerrando em breve - a chamada "primavera marcelista" (SILVA apud REVEZ, 2009, p. 138).

No terceiro arquissema, reúnem-se os versos referentes ao desenho feito pelas crianças no asfalto: o sável, desenhado "sobre o leito negro do asfalto da estrada" (v. 3); "esse peixe da infância que vem na enxurrada" (v. 5). No quarto arquissema, os versos apresentam paralelismo - "Mas desenhem elas o que desenharem" (v. 7) e "e chamem elas o que lhe chamarem" (v. 9). Os dois versos referem-se a ações das crianças, agentes criadores do novo Portugal. Não importa ao sujeito lírico o nome, a definição do que seja esse Portugal futuro; importa ser feliz (v. 10). A imagem da criança remete à infância do país, relação apontada em outro poema de Homem de Palavra[s], "Algumas proposições com crianças": "A criança está completamente imersa na infância / [...] a infância é o elemento da criança como a água / é o elemento próprio do peixe" (BELO, 2004, p. 282). Esse poema, por meio do método das passagens paralelas, também explica outra imagem de "O portugal futuro": o desenho a giz feito pelas crianças pode ser interpretado como o grande leque de opções, o mundo de possibilidades de criação de um novo país: "Se foste criança diz-me a cor do teu país / Eu te digo que o meu era da cor do bibe / e tinha o tamanho de um pau de giz" (BELO, 2004, p. 282).

O verso "portugal será e lá serei feliz" (v.10) encontra-se no centro do poema e se recobre de maior importância interpretativa. Nele, o sujeito lírico revela sua infelicidade no Portugal presente, embora não desista de seu país. Há esperança em um Portugal ainda por 


\section{Conexão Letras}

vir, novamente desenhado. $\mathrm{O}$ fato de ser desenhado a giz aponta para a capacidade ilimitada de mudança, a transitoriedade: o desenho a giz é sempre novo e passível de apagamento. O leito negro do asfalto onde as crianças rabiscam remete ao presente negro de Portugal; é sobre ele que se desenhará um novo país. Essa imagem também pode remeter à lousa: a estrada - caminho, história - é o quadro-negro em que o novo Portugal será traçado.

No quinto arquissema, em que se comenta a dimensão territorial do Portugal futuro, “já nos surge um país descolonizado (BELO, 2004, p. 248): "Poderá ser pequeno como este" (v. 11), "ter a oeste o mar e a espanha a leste" (v. 12). Há uma ideia de satisfação quanto à geografia portuguesa, talvez indicando que não é essa a matéria de "queixa" do sujeito lírico; não é o território do país que o incomoda, mas a ideologia que nele impera. Se considerarmos que o poema foi escrito em meio à guerra colonial, vemos uma postura contrária à política de manutenção do império ultramarino: para o sujeito lírico, as terras africanas não fazem parte do pequeno território português. Elas são algo do qual o Portugal futuro pode prescindir. Há uma contraposição à imagem da "grande nação imperial do Minho ao Timor" (RIBEIRO, 2004, p. 171).

Quanto à territorialidade, Ribeiro explica:

Segundo esta ideologia, a fragmentação do império seria a morte de Portugal e, com ela, a morte de uma ideia de civilização ocidental, que tinha encontrado a sua grandeza e consequente centralidade numa política de expansão imperial [...]. Portugal, ao insistir na perpetuação da divisão do mundo em metrópoles e colónias - como se esta ordem que tinha estado na base da eurocentralidade da idade imperial não estivesse já irremediavelmente perdida - procurava imaginar-se num centro que já só era uma imagem dessa ordem passada e que só um discurso assinalavelmente anacrónico e desfasado da realidade poderia sustentar (2004, p. 190).

Ainda nos versos do quinto arquissema, salienta-se a involução: a renovação de Portugal não começa da raiz aos ramos, mas “desde os ramos à raiz" (v. 13). É preciso destruir o que já está posto e começar tudo de novo, sobre novas bases, abandonando os velhos mitos fundacionais e a identidade nacional forjada a partir de interesses do Estado Novo. Explica-se, pois, a opção de Belo por dizer que o Portugal futuro é um país e não pátria, palavra ideologicamente carregada.

No sexto arquissema, as crianças voltam a ser mencionadas, evocando a alegria e a abertura à mudança que reinarão no Portugal renovado: “À sombra dos plátanos as crianças dançarão" (v. 14); "pode o tempo mudar será verão" (v. 16). Uma rima isolada é a do verso "e na avenida que houver à beira-mar" (v. 15). Aqui, o sujeito lírico segue evocando imagens de verão, florescimento, vida. É à beira-mar que o tempo do inverno pode mudar em verão. O verbo "mudar" aponta a transformação por que o Portugal do presente precisa passar a fim de se tornar o Portugal que o poema propõe. É nesse sentido que Belo caracteriza os poemas de Homem de Palavra[s] como "poesia de intervenção" (BELO, 2004, p. 244).

No último arquissema rímico, temos praticamente um dístico de fechamento. Após sentenciar que gostaria de ouvir o sino da matriz indicando a passagem das horas, o sujeito lírico rejeita esse desejo: "mas isso era o passado e podia ser duro / edificar sobre ele o portugal futuro" (v. 18 e 19). O desejo de ouvir o relógio da matriz representa a saudade da segurança, da certeza e do encantamento que a fé proporcionava; porém, o sujeito lírico sabe que, para edificar o Portugal futuro, é preciso abandonar as raízes. Os dois últimos versos - duros, como indica o v. 18 - rejeitam "a tradição das gerações mortas" (MARX, s.d., p. 6). Ao comentar seu poema no prefácio à segunda edição do livro, Ruy 
Belo reconhece nos versos finais do poema que "estava disposto a renunciar ao passado como condição do futuro" (BELO, 2004, p. 248). Nesse novo tempo, o sino se torna um “objecto inútil", como diz o poema "Lugar onde" (BELO, 2004, p. 259).

Em "O portugal futuro", Belo dialoga com a interpretação gramsciana do marxismo:

Se para grande parte da tradição marxista, a revolução que conduziria à transformação da sociedade teria seu ápice a partir da tomada do Estado, para Gramsci os termos devem ser invertidos, antes de atacar o Estado-burguês seria necessário transformar a força cultural e politica, tornando os ideais revolucionários hegemônicos, isto é, dirigentes da Sociedade Civil, dentro de um sistema de alianças. Esta batalha deveria ser travada no plano das ideias (científicas, filosóficas, religiosas, artísticas, etc), dai a importância do papel desempenhado pelo intelectual, pelo educador e pelo efeito multiplicador dos meios de comunicação social no sentido de mudar a mentalidade, divorciando-a dos sistemas de valores tradicionais e estabelecendo novos valores. É por isso que em Gramsci ganha importância a ideia de uma Reforma Intelectual e Moral, a fim de alcançar uma mudança de mentalidade nas sociedades ocidentais que se constituem de normas, crenças, critérios e convicções (SILVA, s.d.).

É essa reconstrução intelectual e moral que Ruy Belo deseja e antevê. A mentalidade no Portugal futuro será nova; não mais se ouvirá o relógio da matriz - a ideologia católico-salazarista - a marcar a passagem do tempo e a determinar as horas do dia e os rumos da nação.

\section{Considerações finais}

A filosofia marxista, reveladora das falácias por trás dos discursos hegemônicos, traz luz ao questionamento da fé realizado por Ruy Belo em Homem de Palavra[s]. Ainda que não tenha adotado abertamente os conceitos marxistas, o poeta dialoga com vários deles; isso porque a ideia de um país livre de opressões "no se trata únicamente de una moral ni de una filosofía política" (PAZ, 1972, p. 259). A condenação da aliança entre religião e Estado e a opção pela vida material - país, poema, homem - possibilitam o vínculo entre a poética de Belo e as reflexões marxistas.

\section{Referências}

ALTHUSSER, Louis. Ideologia e aparelhos ideológicos do Estado. 3.ed. Lisboa: Presença, 1974.

ANDRADE, Eugénio de. Ostinato rigore. Epitáfios. 9.ed. Porto: Limiar, 1984.

BELO, Ruy. Todos os poemas. 2.ed. Lisboa: Assírio \& Alvim, 2004. v. 1.

BÍBLIA. Português. Bíblia de Jerusalém. São Paulo: Paulus, 2002.

COELHO, Alexandra Lucas. A juventude definitiva de Ruy Belo, Público, Lisboa: 08 ago. 2003. Disponível em: $<$ http://www.publico.pt/culturaipsilon/noticia/a-juventude-definitiva-de-ruy-belo-1160773>. Acesso em: 30 set. 2014.

COMPAGNON, Antoine. O demônio da teoria: literatura e senso comum. Belo Horizonte: UFMG, 2006.

GALIMBERTI, Umberto. Rastros do sagrado. São Paulo: Paulus, 2003.

LECOMPTE, Denis. Do ateísmo ao retorno da religião: sempre Deus? São Paulo:

Loyola, 2000. 


\section{Conexão Letras}

LOTMAN, Iuri. A estrutura do texto artístico. Lisboa: Estampa, 1978.

MOISÉS, Massaud. Ruy Belo. In: . A literatura portuguesa.São Paulo: Cultrix, 2008.

MARX, Karl. O 18 Brumário de Luís Bonaparte. Disponível em: $<$ http://neppec.fe.ufg. br/up/4/o/brumario.pdf>. Acesso em: 25 nov. 2014.

; ENGELS, Friedrich. A ideologia alemã. São Paulo: Martins Fontes, 2001.

PAZ, Octavio (1956). El arco y la lira: el poema, la revelación poética, poesía e historia. 3.ed. México: Fondo de Cultura Economica, 1972.

QUENTAL, Antero de. Causas da decadência dos povos peninsulares nos últimos três séculos. Porto: Typographia Commercial, 1871. Disponível em: <https://archive.org/ details/conferenciasdem00quengoog>. Acesso em: 22 maio 2014.

REAL, Miguel. Portugal: ser e representação. Algés, Portugal: DIFEL, 1998.

RIBEIRO, Margarida Calafate. Epitáfio para os impérios: do lenho e dos barcos naufragados. In:

. Uma história de regressos: império, guerra colonial e pós-colonialismo. Porto: Afrontamento, 2004. p. 167-257.

RICOEUR, Paul. Hermenêutica e ideologias. 2.ed. Petrópolis, Rio de Janeiro: Vozes, 2011. REVEZ, Jorge. Os "vencidos do catolicismo": militância e atitudes críticas. Lisboa:

Universidade Católica Portuguesa, 2009. Disponível em: <https://books.google.com.br/ books?id=Hc6yktZCiBcC\&printsec $=$ frontcover\&hl=pt-BR\#v=onepage $\& q \& \mathrm{f}=$ false $>$. Acesso em: 11 mar. 2014.

SILVA, Anaxsuell Fernando da. Ópio, conforto ou esperança? A concepção de religião em Gramsci. Disponível em: <http://www.academia.edu/472225/\%C3\%93pio_conforto_ou_esperan $\% \mathrm{C} 3 \% \mathrm{~A} 7 \mathrm{a} \_\mathrm{A} \_$concep $\% \mathrm{C} 3 \% \mathrm{~A} 7 \% \mathrm{C} 3 \% \mathrm{~A} 30$ de_religi $\% \mathrm{C} 3 \% \mathrm{~A} 3 \mathrm{o}$ _em Gramsci>. Acesso em: 03 dez. 2014.

TENÓRIO, Waldecy. Escritores, gatos e teologia. Cotia: Ateliê Editorial, 2014. 